\title{
THE LEXICON OF MAJAPAHIT CULINARY AT TROWULAN IN THE GLOBALIZATION ERA
}

\author{
Hendra $^{1^{\star}}$, Rode Ayu Wahyuningputri ${ }^{2}$, Aditya Nova Putra ${ }^{3}$, Farah Levyta ${ }^{4}$ \\ Program Doktoral Pariwisata, Sekolah Tinggi Pariwisata Trisakti, Indonesia \\ Corresponding author's email: hugo_smart@yahoo.com
}

\begin{abstract}
This research aims to describe the form of lingual, naming, and the meaning of lexicon and examines Majapahit Culinary by using a linguistic approach that has similar sounds with global tourism language. The problem studied in the process of naming the Majapahit Culinary that has the same sound as English as the international language. The ethnographic method is used to investigate the language and culture related to culinary based on the understanding of the local community. This research was conducted in Trowulan. Data collection uses in-depth interview methods and observations of the participation of informants. All data is reviewed using analisis domain, taxonomy, componential and themes, obtained from written sources including inscriptions and literature from Majapahit and from the time before and afterwards. The sources of research data are verbal words of the informants as speakers. Data collection was carried with participant observation techniques and interviews. Data analysis was carried out with four activities as collection, reduction, presentation and verification. The result of the Majapahit culinary analysis that has naming which can be used as the basis for the reference of the global sound are five Majapahit culinary, they are Letlet, Wok, Kwelon Dodol and Lepet. Those five Majapahit culinary will become a reference in the promotion of Majapahit culinary in international tourism.
\end{abstract}

Kata Kunci: Majapahit Culinary; Lexicon Culinary Naming; Global Tourism Promotion

\section{INTRODUCTION}

Tourism sector as a "National Strategic", which continuously creates benefit distribution such as creating job vacancy, increasing other business income, and encourage the government to build and maintain infrastructure. Through the movement of NAWA CITA, Ministry of Tourism has targeted 20 million of foreign tourist visits and domestic traveler 
movements of 275 million trips in 2019. According to article number 10 year of 2009 concern in Tourism, there are several terms that connected in defining the concept of tourism, as follows: 1) Travel, 2) Tourist and 3) Tourism which the three terms of words have a different emphasis when defined.

Historical-based tourism is an attraction for foreign tourists who visiting Indonesia and is a goverment program in sustainable tourism. The potential of attractive historical-based tourism makes Indonesia have the opportunity to become a historical-based tourist destination that attracts tourists. On of the historical heritage-world scale known is the history of Majapahit Kingdom, which is based in East Java, Indonesia, who has ever stood around 1293 to 1527 AD and currently considered as no longer available. Majapahit as one of cultural heritage that are considered extinct still having the historical record culture in a few believed to be still lived on by the ancestor of the Majapahit.

The existence of Majapahit culinary as one of the cultural heritage in the Nusantara Gastronomy can still be traced throught a historical record in several places that are believed to have been occupied by the descendants of the Majapahit community. Culturally culinary describes the local identity of a cultural supporter that characterizes the environment and culture and depicting a representation, regulations, consumption and the production (Wurianto, 2008; Oktavio \& Indrianto, 2019). Therefore, it can be formulated that culinary is a cultural product and is closely related to the community. Stajcic (2013) defining culture as a series of values, knowledge, rituals, habits, lifestyles, attitudes, beliefs, folklore, rules and customs that identify a number of certain groups. According to Stajcic, food and culture are important since in reality, the food and culture are very closed. Stajcic (2013:8) also adds that food might send naturally different meanings from one culture to another.

Language is a communication tools between community members in the form of sound symbols produced by human (Keraf, 1997). Language is basically an element in studying culture. It means that culture will be reflected in language. This is show that human cultural activities cannot be separated from the language. Duranti (1997) also emphasizes that to describe a culture as well as descripts languages. In the Global tourism era, the promotion of 
Majapahit Culinary as an international tourist attraction must consider the language lexicon as a promotional language.

Based on the reasons mentioned above, the research on Majapahit Culinary is correctly done using a culinary linguistic approach which is a new branch in linguistics, food studies related to food or cuisine from a linguistic perspective, to fill the interstices of some research that has been carried out former about language and food. It is important to implement the linguistic studies to see the meaning of food and language and cultural realtions in order to have a greater selling valies for the community of global culinary cultural tourist.

\section{Lexicon}

The word lexicon itself comes from Greek, Lexicon which means 'word' or 'vocabulary'. Adjectives are lexical, something related to lexicón (Sudaryat, 2009). Lexicon commonly called vocabulary can be interpreted (a) Wealth of words owned by a languange; (b) All words contained in a languange; (c) Idiolek; words that are controlled by someone or dialect; (d) Term; words used in a field of science; (e) Glossarium; simpel dictionary, dictionary in compact form, list of words in certain fields with the explanation; (f) Language componen that contain all information about meaning and use; (g) Dictionary; list of a number of words or phrases from a language complied alphabetically accompanied by limits and other information (Adiwimarta, 1978; Kridalaksana, 1982; KBBI, 1988); and (h) Enslikopedi; universal works that collect a description of various branches of specific science or fields in separate articles and arrannged by alphabetical. Therefrom, lexicon or vocabulary is a number of words in a languange that is used actively and passively, both those still spread among the public and those that have been collected in the form of a dictionary. Lexicon is a collection of lexemes. The meaning of lexeme is called lexical meaning.

\section{Naming}

One of approach that can be used to assess traditional culinary in language and culture is anthropolinguistic. Anthropolinguistic is a languange study as a source of culture and speaks 
as a cultural practice (Duranti, 1997). The ultimate goals of anthropolinguistic study is to analyze language by taking data directly from speakers. This is known as ethnography or participant observation. The main idea of this approach is that language researchers will understand the language and relationship with all aspects of culture better by watching their own use of language in a natural social context (Danesi, 2004). Language studies in the anthropolinguistic field with the language role in life. Culture is the most dominant aspect of human life so in a hierarchy the anthropolinguistic languange studies are analyzed in relation to culture (Sibarani, 2013). Naming and defeating is the two mining processes of a concept which refere to a referent that is outside the language. In giving the name of an object, events, or incident, there are several symptoms of an idiom. Words or idioms are mention or naming something which experienced by the user. Giving the name of an object, events or incidents, it can be classified as naming based on the copy of sound or onomatopoeia, that is a primitive basis in the mention of objects. Onomatopoeia is the process of creating a word that phonetically imitates because of the copy of sound produced by the objects. Within the language promotion in the tourism, food naming that has the same sound as international language will make it easier for foreigner to memorize the existing words so that the existing culinary culture can be increasingly popular in the global tourism era.

\section{Lexicon of Traditional Foods}

Traditional food or local culinary is a food product consumed by a community group or served in special celebrations at certain times as a legacy of the previous generation. This type of food is made with a prescription from generation to generation so that it is almost without modification and makes it different from other regional culinary. Traditional cuisine becomes a local identity because it is part of the totality of community culture, such as processiong procedures, its role in community culture, and celebration procedures in the event, as well as cooking récipes that are maintained (Tyas, 2017). Culinary or traditional food is one of the cultural treasures that must continue to be explored as one of the nation's assets. This research is expected to be able to raise the image of Majapahit culinary so that it can be 
known as one of the legacy of the cultural heritage packaged in tourism packages both nationally and internationally. The lexicon of Majapahit food culinary names has a meaning that must be studied so that indirectly also preserve the traditional culinary of Majapahit. The study of the meaning of naming Majapahit cuisine is also important as a documentation that can be inherited in the next generation. Based on the phenomenon, research on Majapahit culinary is very important to see the process of Word formation and also the process of Majapahit cuisine naming and the cultural background that surround it. The anthropologists position eating as a very important culture because it is inseparable from human life.

\section{METHOD}

The method is descriptive. Data collecting techniques, using participants observation techniques, interview techniques, and bibliography technique studies. The source of the data of the Majapahit culinary interview from the Trowulan Museum represented by Mrs. Kiki and team. Whereas, the research object is traditional Majapahit food from literature data.

\section{RESULT AND DISCUSSION}

The Kingdom of Majapahit is the largest kingdom in Indonesia in the past. The kingdom was established in $1293 \mathrm{AD}$ and reached its golden peak under the reign of King Hayam Wuruk in 1350 AD - 1489 AD, and fallen around 1520 AD. The greatness of the Kingdom of Majapahit is also reflected in its diverse relics and found spread in East Java, especially on the Trowulan site which has been agreed by experts as the former capital of the Majapahit Kingdom. Majapahit culinary is obtained from written sources including inscriptions and literature originating from Majapahit era as well as from the period before and after it. Another written sources targeted in the research are foreign news written by Chinese, Arabic, and European people who had visited Java at that time. In addition, it is also done through research on temple reliefs and other findings. Based on data written by Mambo (1983), Majapahit culinary can be divided into cuisine and cake. 


\section{Type of Cuisine}

The types of food/cuisine are mentioned based on the inscription data. The inscriptions are Taji Inscription 901 AD, Panggumulon Inscription 902 AD, Watukura Inscription 902 AD, Mantyasih Inscription I 907 AD, Mantyasih Inscription III, Rukam Inscription 907 AD, Sanggiran Inscription 928 AD, Gelung-gelung Inscription 929 AD, Jeru-Jeru Inscription 930 AD, Alasantan Inscription 939 AD, and Paradah Inscription 943 AD.

The types of food/cuisine include:

1. Asin asin: Marinated meat or fish

2. Den asing: Meat that has been dried and becomes jerked meat

3. Kadiwas: Dried fish meat

4. Kawan: Types of cuisine from Gurame fish

5. Bilunlun: Name of the dish from fish

6. Hantiga: Eggs

7. Rumaban: Dishes made from fish/scallops

8. Nasi mantiman: This dish is still unknown

9. Dain kakap: Dried snapper

10. Dain kadawas: Dried pomfret

11. Layar layar: Dishes made from stingrays or sailfish

12. Huran (Shrimp)

13. Bala bala: A kind of fish

14. Sayur hadanan: Buffalo meat that is processed into side dishes or vegetable

15. Sayur wedus: Vegetables made from goat meat

16. Kasyan: Special dish. The ingredients used are still unknown

17. Kwelon: The dish is still unknown

18. Rumwarumwah: The dish contains a slice of meat with raw vegetables

19. Kuluban: Boiled fresh vegetables

20. Dudutan: Fresh vegetables

21. Tetis: Chili sauce or shrimp paste 
22. Letlet: Special cooked meat. Less definitely meat which is used

23. Tahulan: The dish is still unknown

24. Ikan Wagalan: A dish made from freshwater fish. Fish is still unknown

25. Haryyas: A dish made from the core part of banana stem

26. Sunda: The dish is still unknown

27. Haran-haran: Charcoal-cooked/baked dishes

28. Den Kakap: Dried snapper

29. Taniri (Mackerel)

30. Hnus (Squid)

31. Hadanan, Wok, Kidan, Wus: A dish made from buffalo, pork, deer, and goat

32. Den Hasin: A dish has the same possibilities a number 2 cuisine, Den Asin. The dish is still unknown

33. Den Hanan: Dried meat (unsalted)

34. Den Tarun: Dried meat

35. Hantrini Inari: Dried egg

36. Nasi Paripurna: Lemak Rice consumed with side dishes. It is predicted to be similar to tumpeng rice.

37. Ikan Duri: This dish is still unknown

38. Dlag Inarin Myan Hantrini: Fish cork fried with eggs

39. Gtam (Crab)

40. Sayur Sapi: Vegetables made from beef or beef soup

41. Atah-Atah: Raw vegetables salad. The ingredients are still unknown

42. Sanasanan: Baked dishes

43. Dalamman: A dish made from the entrails of an animal

44. Hinaryyasan: A dish made from a part of banana tree (core)

45. Nasi Dandanani Hinaru: This dish is still unknown

46. Ranak: This dish is still unknown

47. Sangasangan: Baked dishes. The ingredients are still unknown 
48. Aryya: This dish is predicted similar with number 44. It is made from a part of Banana trees but it is not known where the difference between the two dishes is

49. Hanwiga: Dried eggs

50. Atat Pihan: A dish made from nuts

51. Sangkab: This dish is still unknown

52. Wulu: This dish is still unknown

53. Kandari: A dish made from fish

54. Slar: A dish made from small fish

55. Capacapa: A dish made from turtle meat

56. Kasyan Lgi: A dish is similar with number 16, but Kasyan Lgi is sweeter

57. Tawangan: This dish is still unknown

58. Alap-Alap: This dish is still unknown

59. Bijanjan: This dish is still unknown

60. Celen dan Hangsa: A dish made from wild boar and goose

61. Wuku: This dish is still unknown

62. Cinanganan: A baked dish. The imgredients are still unknown

63. Iwak Khas: A dish made of shellfish

\section{Types of Cake}

1. Amwil-amwil/Ambel-Ambel: Small snacks. It is predicted similar to kletikan (snacks) from Java

2. Kasyan: Special cooked snacks. Usually taste sweet

3. Kwelan: This type of cake is still unknown

4. Aranak/Ranak: This type of cake is still unknown

5. Atat Mipihan: Snacks made from nuts

6. Dwadwal (Dodol)

7. Kura: According to the data, Kura is an abon made of turtle meat. Until now it is still unknown 
8. Wuku: A snack made from grains

9. Rih: This type of cake is still unknown

10. Hasam/Asem: A sweet made from Tamarind fruit

11. Rima: This type of cake is still unknown

12. Rujak: Rujak made from fruits. It is not known whether they use shrimp paste or not

13. Ketan/Laketan: It is predicted similar with urap ketan exist today. It is usually added by grated coconut or brown sugar

14. Tape: A sticky rice with yeast. It is predicted similar with tape ketan that exist today

15. Bubur: It is predicted similar with today's porridge. The raw material is rice

16. Puli: Special snack made from rice

17. Lepet: Snacks made from sticky rice and wrapped with palm or coconut leaves then boiled 18. Ghretapura: It is predicted similar with sumsum porridge which have a sweet taste

18. Kipin: It is predicted similar with kerupuk (crackers) today.

19. Carana: Snacks wrapped in leaves

20. Modaka/Modakanda: Snacks that have sweet taste. It is usually made from preserved fruit

21. Landuga: Snacks that have sweet taste. It is predicted similar with number 21 .

22. Mandaga: Also known as cone cake. Mandaga is predicted as snack made rom rice flour which is filled with grated coonut and brown sugar.

23. Kupatay: Dish made from rice then being wrapped in palm or coconut leaves which then shaped into a rectangle. It is predicted similar with ketupat today.

24. Caru: Snacks made from butter and milk. Caru is predicted as one of dish used for (sajen) offerings.

25. Atak Sisilan: Snacks made from peanut

26. Uwi: Snacks made from sweet potato, can be processed by frying, grilling, or boiling

27. Wajik: Snacks made from sticky rice and brow sugar. Estimated to be the same as the wajik that exist today. 
28. Bubur Susu Sudha: There are differences opinion in this cake. Some thought that this cake was a rice porridge that was given with milk and others thought that it was a sumsum porridge made from rice without brown sugar

29. Bubur Pehan: It is predicted the same as milk porridge (number 29)

30. Bubur Gula Liwet: It is predicted as a dish that is cooked/blended together with Brown sugar

31. Jawadah: Snacks made from sticky rice, coconut and sugar to make it taste sweet

32. Amik-Amikan: Thought to be snack that taste sweet

33. Parasi: Snacks that taste sweet

34. Carah: Snacks that taste sweet

Words or idioms are mention or naming of something experienced by the user. In naming the objects, events or incidents, can be classified as naming based on sound imitation or onomatope, it is a primitive basis in the mention of objects. Based on the result of the descriptive analysis of the Majapahit food lexicon in Trowulan, there are 63 food datas and 35 snacks analyzed by the lexicon structure according to the similarity of the sound that is in international discussion, English. Based on the structure of pronunciation in English is influenced by different vocals of pronunciation in Indonesian, from the vocal alphabet that has the same sound are vowels "e" dan "o", letter i and a in the end of the word, the consonants of the alphabet are b, c, d, f, g, h, j, k, I, m, n, p, q, r, s, t, v, w, x, y, z. From the name list of interviews and literature studies found data that there are 5 food namings that has the same vocal sound, as follows lelet, kwelon, Wok, dodol and lepet. Wheares if it refers to the similarity of naming form the consonant letter are Asin asin (salty), kadiwas, Kawan, Bilunlun, hantiga, rumaban,nasi mantiman (rice), dain kakap (snapper), dain kadawas, layar layar, Huran, Bala bala, sayur hadanan (vegetable), kasyan, kwelon, rumwahrumwah, dudutan, tetis, letlet, tahulan, Ikan wagalan (fish), Sunda, Den kakap (snapper), Taniri, Wok, hadanan, Kidan, Wus, Den Hasin, Den Hanan, Den Tarun, Hantrini Inari, Nasi Paripurna (rice), Ikan Duri, Sayur Sapi (Beef Soup), Atah-Atah, Sanasanan, Dallaman, Hinnaryyasan, Nasi Dandanari Hinaru, 
Ranak, Sangasangan, Arrya, Hanwiga, Atat Pihan, Sangkab, Wulu, Kandari, Slar, Capacapa, Kasyan Lgi, Tawangan, Alap-Alap, Bijanjan, Celen dam Hangsa, Wuku, Cinanganan, Iwak Khas, Anwil-Anwil/Ambel-Ambel, Kasyan, Kwelan, Aranak/Ranak, Atat Mipihan, Dwadwal (Dodol), Kura, Wuku, Rih, Hasam/Asem, Rima, Rujak, Ketan/Laketan (Sticky Rice), Tape, Bubur (porridge), Puli, Lepet, Ghretapura, Kipin, Canara, Modaka/Modakanda, Landuga, Mandaga, Kupatay, Caru, Atak Sisilan, Uwi, Wajik, Bubur Susu Sudha (Milk Porridge), Bubur Pehan (porridge).

\section{CONCLUSIONS}

Culinary naming in the global market must follow the same sound spoken in international language so that the pronunciation of the Majapahit culinary lexicon will have the same sound. The naming of the Majapahit Culinary Lexicon is based on sound imitation, pronunciation in English that is influenced by a different vocal pronounciaton with Indonesian, form the vowel alphabets that have the same sound are "e" dan "o" from consonant letters are b, c, d, f, g, h, $\mathrm{j}, \mathrm{k}, \mathrm{l}, \mathrm{m}, \mathrm{n}, \mathrm{p}, \mathrm{q}, \mathrm{r}, \mathrm{s}, \mathrm{t}, \mathrm{v}, \mathrm{w}, \mathrm{x}, \mathrm{y}, \mathrm{z}$. From the results of the analysis, there are five foods at the culinary that has the same sound as English, Letlet, Kwelon, Wok, Dodol, and Lepet. Those five Majapahit culinary will be a reference in the promotion of Majapahit culinary in international tourism.

\section{REFERENCES}

Adiwimarta, Sri Sukesi. (1978). Tata istilah Bahasa Indonesia. Jakarta: Pusat Bahasa.

Kridalaksana, Harimurti. (1982). Kamus linguistik. Jakarta: Gramedia.

Mambo, W dan Nurhayati H. 1992. Makanan dan pakaian pada masa Majapahit. Direktorat Jenderal Kebudayaan.

Nastiti, T. S. (1989). Minuman pada masyarakat Jawa kuno. Pusat Penelitian Arkeologi Nasional.

Oktavio, A., \& Indrianto, A. T. L. (2019). Social economic perspectives of homecoming tradition: An Indonesian context. Katha, 15(1), 46-65. https://doi.org/10.22452/KATHA.vol15no1.3

Spradley, J. A. (1997). Metode Etnografi. (terjemahan). Yogyakarta: Tiara Wacana.

Sudaryanto. (1993). Metode dan Aneka Teknik Analisis Bahasa: Pengantar Penelitian Wahana Kebudayaan secara Linguistik. Yogyakarta: Duta Wacana Press. 